\title{
Age of Tephra Beds at the Ocean Point Dinosaur Locality, North Slope, Alaska, Based on $\mathrm{K}-\mathrm{Ar}$ and ${ }^{40} \mathrm{Ar} /{ }^{39} \mathrm{Ar}$ Analyses
}

\section{U.S. GEOLOGICAL SURVEY BULLETIN 1990-C}






\section{AVAILABILITY OF BOOKS AND MAPS OF THE U.S. GEOLOGICAL SURVEY}

Instructions on ordering publications of the U.S. Geological Survey, along with the last offerings, are given in the current-year issues of the monthly catalog "New Publications of the U.S. Geological Survey." Prices of available U.S. Geological Survey publications released prior to the current year are listed in the most recent annual "Price and Availability List." Publications that are listed in various U.S. Geological Survey catalogs (see back inside cover) but not listed in the most recent annual "Price and Availability List" are no longer available.

Prices of reports released to the open files are given in the listing "U.S. Geological Survey Open-File Reports," updated monthly, which is for sale in microfiche from U.S. Geological Survey Book and Open-File Report Sales, Box 25425, Denver, CO 80225.

Order U.S. Geological Survey publications by mail or over the counter from the offices given below.

\section{BY MAIL}

\section{Books}

Professional Papers, Bulletins, Water-Supply Papers, Techniques of Water-Resources Investigations, Circulars, publications of general interest (such as leaflets, pamphlets, booklets), single copies of periodicals (Earthquakes \& Volcanoes, Preliminary Determination of Epicenters), and some miscellaneous reports, including some of the foregoing series that have gone out of print at the Superintendent of Documents, are obtainable by mail from

\section{U.S. Geological Survey, Book and Open-File Report Sales Box 25425 \\ Denver, CO 80225}

Subscriptions to periodicals (Earthquakes \& Volcanoes and Preliminary Determination of Epicenters) can be obtained ONLY from

\section{Superintendent of Documents \\ U.S. Government Printing Office Washington, DC 20402}

(Check or money order must be payable to Superintendent of Documents.)

\section{Maps}

For maps, address mail orders to

$$
\begin{gathered}
\text { U.S. Geological Survey, Map Sales } \\
\text { Box 25286 } \\
\text { Denver, CO } 80225
\end{gathered}
$$

Residents of Alaska may order maps from

$$
\begin{aligned}
& \text { U.S. Geological Survey, Map Sales } \\
& 101 \text { Twelfth Ave. - Box } 12 \\
& \text { Fairbanks, AK } 99701
\end{aligned}
$$

\section{OVER THE COUNTER}

\section{Books}

Books of the U.S. Geological Survey are available over the counter at the following U.S. Geological Survey offices, all of which are authorized agents of the Superintendent of Documents.

- ANCHORAGE, Alaska--4230 University Dr., Rm. 101

- ANCHORAGE, Alaska--605 West 4th Ave., Rm G-84

- DENVER, Colorado--Federal Bldg., Rm. 169, 1961 Stout St.

- LAKEWOOD, Colorado-- Federal Center, Bldg. 810

- MENLO PARK, California--Bldg. 3, Rm.3128,345 Middlefield $\mathrm{Rd}$.

- RESTON, Virginia--National Center, Rm. 1C402, 12201 Sunrise Valley Dr.

- SALT LAKE CITY, Utah--Federal Bldg., Rm. 8105, 125 South State St.

- SAN FRANCISCO, California--Customhouse, Rm. 504, 555 Battery St.

- SPOKANE, Washington--U.S. Courthouse, Rm. 678, West 920 Riverside Ave.

- WASHINGTON, D.C.--U.S. Department of the Interior Bldg., Rm. 2650, 1849 C St., NW.

\section{Maps}

Maps may be purchased over the counter at the U.S. Geological Survey offices where books are sold (all addresses in above list) and at the following Geological Survey offices:

- ROLLA, Missouri--1400 Independence Rd.

- FAIRBANKS, Alaska--New Federal Building, 101 Twelfth Ave. 
Chapter C

\title{
Age of Tephra Beds at the Ocean Point Dinosaur Locality, North Slope, Alaska, Based on $\mathrm{K}-\mathrm{Ar}$ and ${ }^{40} \mathrm{Ar} /{ }^{39} \mathrm{Ar}$ Analyses
}

\author{
By JAMES E. CONRAD, EDWIN H. MCKEE, and \\ BRENT D. TURRIN
}

A multidisciplinary approach to research studies of sedimentary rocks and their constituents and the evolution of sedimentary basins, both ancient and modern 


\title{
U.S. DEPARTMENT OF THE INTERIOR MANUEL LUJAN, JR., Secretary
}

\author{
U.S. GEOLOGICAL SURVEY \\ Dallas L. Peck, Director
}

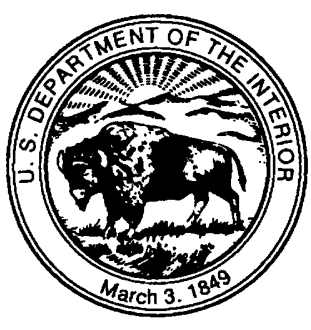

Any use of trade, product, or firm names in this publication is for descriptive purposes only and does not imply endorsement by the U.S. Government

For sale by

Book and Open-File Report Sales

U.S. Geological Survey

Federal Center, Box 25425

Denver, CO 80225

\section{Library of Congress Cataloging-in-Publication Data}

Conrad, James E.

Age of tephra beds at the Ocean Point dinosaur locality, North Slope, Alaska, based on $\mathrm{K}-\mathrm{Ar}$ and ${ }^{40} \mathrm{Ar} /{ }^{39} \mathrm{Ar}$ analyses/by James E. Conrad, Edwin H. McKee, and Brent D. Turrin.

P. Cm. -- (Evolution of sedim
(U.S. Geological Survey bulletin; 1990-C)

Includes bibliographical references.

Supt. of Docs. no.: I 19.3: 1990-C

1. Volcanic ash, tuff, etc.--Alaska--Ocean Point Region. 2. Geology, Stratigraphic--Cretaceous. 3. Geology--Alaska--Ocean Point Region. 4. Potassiumargon dating. 5. Prince Creek Formation (Alaska) I. McKee, Edwin H. II. Turrin, Brent D. III. Title. IV. Series. V. Series: U.S. Geological Survey bulletin: 1990-C. QE75.B9 no. 1990-C

[QE461]

$557.3 \mathrm{~s}-\mathrm{-dc} 20$

[552'.23] 


\title{
CONTENTS
}

\author{
Abstract C1 \\ Introduction C1 \\ Geologic setting C1 \\ Methods C2 \\ Results C4 \\ Conventional K-Ar analyses $\mathbf{C 4}$ \\ ${ }^{40} \mathrm{Ar} /{ }^{39} \mathrm{Ar}$ analyses $\mathrm{C4}$ \\ Sample M86LPA19 C5 \\ Sample 84ACr180Y C7 \\ Sample M86LPA14 C7 \\ Sample 86ACr019 C10 \\ Sample M86LPA9 C10 \\ Discussion C11 \\ References cited $\mathbf{C 1 2}$
}

\section{FIGURES}

1. Map showing locations of dated tephra beds of Prince Creek Formation, northern Alaska C2

2. Composite schematic stratigraphic section of Prince Creek Formation C3

3. Scanning electron micrographs of untreated glass shards from Colville River tephra beds $\mathbf{C 3}$

4. Diagrams showing results of ${ }^{40} \mathrm{Ar} /{ }^{\beta 9} \mathrm{Ar}$ analyses $\mathbf{C 8}$

5. Graph showing best age estimates for Colville River tephra beds C11

\section{TABLES}

1. Results of conventional K-Ar analyses of Colville River tephra beds C4

2. Results of ${ }^{40} \mathrm{Ar} /{ }^{39} \mathrm{Ar}$ analyses of Colville River tephra beds C6

3. Summary of K-Ar and ${ }^{40} \mathrm{Ar} /{ }^{39} \mathrm{Ar}$ ages of Colville River tephra beds C10 
Cover. Looking upsection (north) along Colville River, Alaska, at 30-m-high bluffs of Cretaceous nonmarine siltstone and sandstone of Prince Creek Formation, unconformably overlain by Pliocene and Quaternary Gubik Formation. Low bench in foreground marks a dinosaur-bone-bearing bed. Drawing by J.F. Vigil, from photograph by E.M. Brouwers. 


\title{
Age of Tephra Beds at the Ocean Point Dinosaur Locality, North Slope, Alaska, Based on $\mathrm{K}-\mathrm{Ar}$ and ${ }^{40} \mathrm{Ar} /{ }^{39} \mathrm{Ar}$ Analyses
}

\author{
By James E. Conrad, Edwin H. McKee, and Brent D. Turrin
}

\begin{abstract}
Tephra layers exposed above and below dinosaur-bonebearing beds of the Prince Creek Formation, North Slope, Alaska, provide an opportunity to date these beds by radiometric methods. Although the tephra layers contain few or no potassium-bearing minerals, they are composed of apparently unaltered glass shards that appear to be suitable for $\mathrm{K}$-Ar dating. ${ }^{10} \mathrm{Ar} /{ }^{39} \mathrm{Ar}$ incremental-heating analyses were conducted in order to evaluate the accuracy of the $\mathrm{K}-\mathrm{Ar}$ ages, and these analyses indicate that most of the tephra layers have undergone only minor argon loss. Most of the K-Ar and ${ }^{\circ 0} \mathrm{Ar} /{ }^{39} \mathrm{Ar}$ ages are analytically indistinguishable and indicate that the bone-bearing beds are between 68 and $71 \mathrm{Ma}$. The dinosaur-bone-bearing beds of the Prince Creek Formation therefore appear to be of latest Cretaceous age (the Cretaceous-Tertiary boundary is currently considered to be about $66 \mathrm{Ma}$ ).
\end{abstract}

\section{INTRODUCTION}

The age of dinosaur-bone-bearing beds of the Prince Creek Formation exposed along the Colville River near Ocean Point, Alaska (fig. 1), has aroused much interest in the geologic community because of its bearing on the hypothesis that the Cretaceous-Tertiary extinction was caused by an asteroid impact (Alvarez and others, 1980). Paleontological studies based on marine faunas have suggested that at least part of the section exposed along the Colville River is Paleocene in age (Marincovich and others, 1985), and a fission-track age on zircon of $50.9 \pm 7.7 \mathrm{Ma}$ from a tephra bed near the dinosaur-bone-bearing beds (Carter and others, 1977) seemed to confirm this age designation. If the Paleocene age is valid it would extend the age range of dinosaurs in Alaska into the Cenozoic and would cast doubt on the impact hypothesis as an explanation for the

Manuscript approved for publication, April 15, 1991. extinction of the dinosaurs. Other studies suggest that at least the part of the Prince Creek Formation that contains the dinosaur bones is Late Cretaceous in age (McDougall, 1987; Brouwers and others, 1987).

Abundant tephra beds exposed along the Colville River bluffs about $7 \mathrm{~km}$ west of Ocean Point (fig. 1) contain material suitable for dating by K-Ar techniques and provide an excellent means for establishing the age of these sedimentary rocks. This paper presents the results of conventional $\mathrm{K}-\mathrm{Ar}$ and ${ }^{40} \mathrm{Ar} /{ }^{39} \mathrm{Ar}$ analyses of glass shards from the tephra beds and evaluates the suitability of these relatively old rhyolitic glasses for ${ }^{40} \mathrm{Ar} /{ }^{39} \mathrm{Ar}$ and $\mathrm{K}$-Ar dating techniques.

\section{GEOLOGIC SETTING}

The Prince Creek Formation consists of a series of poorly consolidated sandstones, siltstones, and shales that dip gently to the northeast (Gryc and others, 1951; Detterman and others, 1975). The Colville River has cut into this formation, creating a bluff that stands some $20-30 \mathrm{~m}$ high and extends many kilometers upriver from Ocean Point.

At least 10 tephra beds are exposed in the section northwest of Ocean Point, and volcanic glass is a major component in the sedimentary rocks in much of the remainder of the section (fig. 2). Almost all the tephra beds are associated with dark beds that are rich in organic matter and probably represent flood-plain deposits (Phillips, 1988). Most of the dinosaur bones are found in these organic-rich horizons, although scattered bones occur in some sandstone beds.

The tephra beds stand out as resistant, buff-colored strata ranging from about $1 \mathrm{~cm}$ to $2 \mathrm{~m}$ in thickness. They interfinger with the organic-rich beds, pinching out over distances of hundreds of meters. The tephra is composed almost entirely of rhyolitic glass shards, although clays, quartz, and feldspar are minor constituents, and altered biotite grains occur in some of the tephra beds. The glass 
shards appear well preserved with sharp and ragged edges; whole bubbles remain (fig. 3). Microscopic examination revealed no traces of devitrification or alteration of the glass shards, suggesting that the glass is suitable for radiometric dating. The completely unabraided character of the fragile shards indicates they are airfall deposits that have not been transported by water for any distance. Clay minerals are generally a minor component of most of the tephra beds, although some beds are completely altered to clay. The differences in alteration are probably attributable to differences in initial composition of the glass and differences in local ground-water effects.

Because there are few or no potassium-bearing mineral phases in the tephra beds, glass shards were used for $\mathrm{K}$-Ar and ${ }^{40} \mathrm{Ar} /{ }^{39} \mathrm{Ar}$ dating of the beds. Although relatively young tephra deposits are routinely dated by the $\mathrm{K}-\mathrm{Ar}$ method, the reliability of glass older than about 15 million years for dating by this technique is questionable because glass tends to readily devitrify. This devitrification results in the redistribution or loss of radiogenic argon, which in turn leads to anomalous ages (Fleck and others, 1977). Glass shards from the Colville River tephra beds appear fresh and well preserved. In order to evaluate the accuracy of the ages, multiple $\mathrm{K}-\mathrm{Ar},{ }^{40} \mathrm{Ar} /{ }^{39} \mathrm{Ar}$ total-fusion, and incremental, or age-spectrum, ${ }^{40} \mathrm{Ar} /{ }^{39} \mathrm{Ar}$ analyses were performed and the resulting ages compared. The age-spectrum analyses in particular provide a means to evaluate the possibility of alteration or diffusion that would lead to anomalous ages.

\section{METHODS}

Prior to analysis, the tephra samples were disaggregated and sieved to 100 to 140 mesh (149 to $105 \mathrm{mi}$ crometers). After ultrasonic cleaning to remove dust and clays adhering to the shards, a combination of magnetic and heavy-liquid separation techniques was used to produce a pure glass separate. In order to minimize contamination and insure homogeneity, a variable-density heavy-liquid column was used to separate the glass shards into a relatively narrow specific-gravity range. This technique also helps to eliminate grains with a greaterthan-average area of altered surfaces. For example, it was found that bubble-wall shards, with a higher surface-tovolume ratio than the bubble-corner shards, tended to be slightly less dense, presumably owing to a greater percentage of surface alteration.

The glass separates were etched in 5-percent hydrofluoric acid for approximately 45 seconds to remove surface alteration and reduce atmospheric-argon contamination. Conventional $\mathrm{K}-\mathrm{Ar}$ analyses on shards not treated with acid gave ages as much as 10 percent younger than ages from the acid-treated samples. Furthermore, the nontreated samples had four times the atmospheric-argon contamination displayed by the treated samples; this contamination is significant in determination of the precision ( \pm factor) of the age.

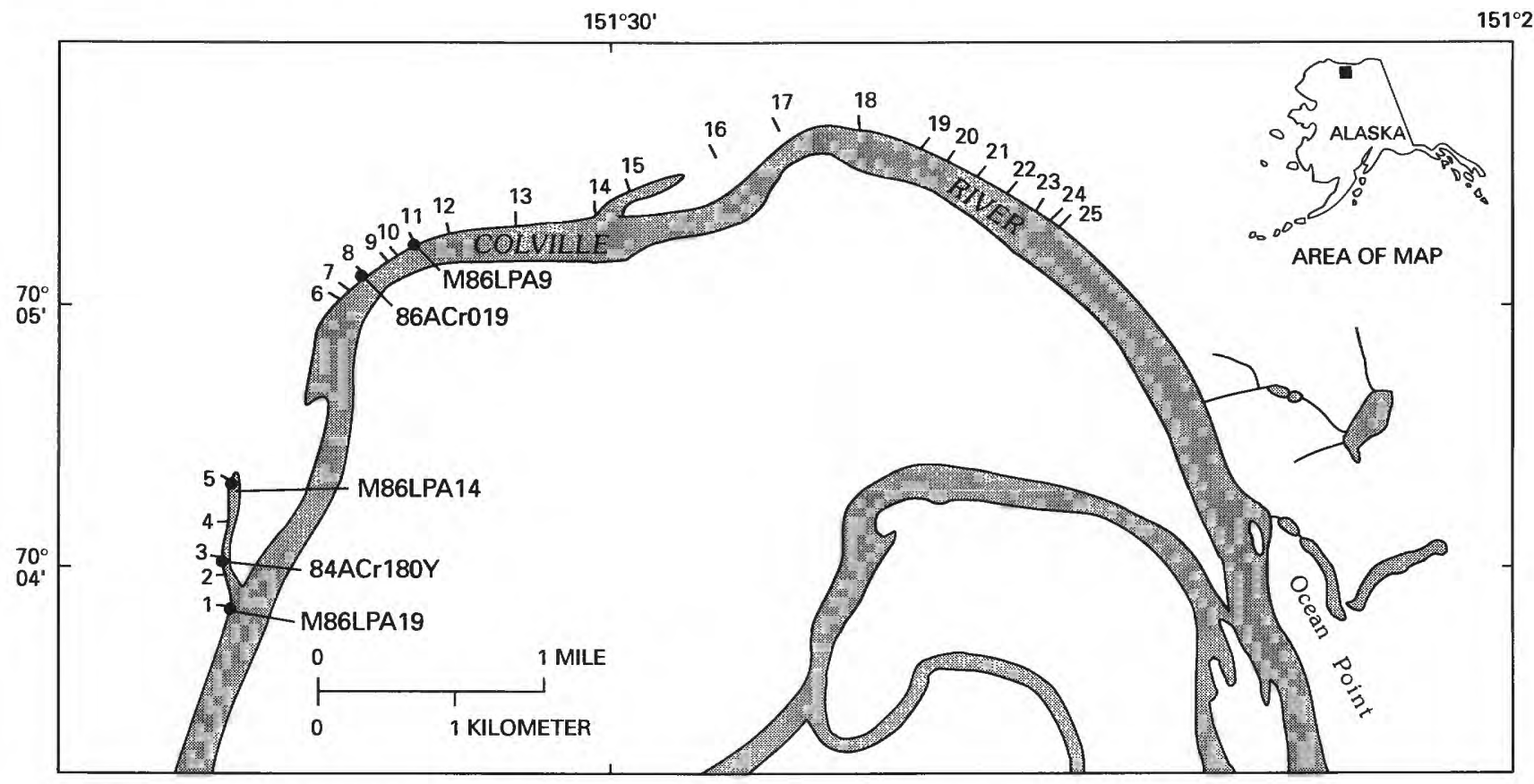

Figure 1. Locations of dated tephra beds of Prince Creek Formation, northern Alaska. Sample numbers correspond to tephra samples dated by $\mathrm{K}-\mathrm{Ar}$ and (or) ${ }^{40} \mathrm{Ar} /{ }^{39} \mathrm{Ar}$ techniques, discussed in text. Numbers $1-25$ mark locations of measured sections (Phillips, 1988). 
Conventional $\mathrm{K}$-Ar analyses were performed using standard isotope-dilution techniques similar to those described by Dalrymple and Lanphere (1969). A $60^{\circ}$-sector, 15.2-cm-radius, Nier-type mass spectrometer was used for argon analysis. Potassium analyses were performed by a lithium metaborate flux fusion-flame photometry technique, using lithium as an internal standard (Ingamells, 1970).



EXPLANATION

$\therefore \therefore$ Interdistributary-bay deposits
$\therefore \therefore$ Nonmarine deposits
$\mathrm{t} \quad$ Dated tephra bed
$\mathrm{v} \quad$ Vertebrate fossil occurrence

Figure 2. Composite schematic stratigraphic section of Prince Creek Formation exposed along Colville River $7 \mathrm{~km}$ west of Ocean Point, northern Alaska. Total stratigraphic section is $178 \mathrm{~m}$. Horizons from which samples were collected and radiometrically dated are labeled with sample numbers (see fig. 1 for locations). Modified from Phillips (1988).
Samples used in the ${ }^{40} \mathrm{Ar} /{ }^{39} \mathrm{Ar}$ experiments were heated by two different techniques-induction coil (Dalrymple and Lanphere, 1969) and continuous laser (York and others, 1981). Samples heated by induction coil-the more conventional technique-were irradiated in the U.S. Geological Survey TRIGA ${ }^{1}$ nuclear reactor (Denver, Colo.) for a period of 20 hours at a power of 1 megawatt. Irradiation

\footnotetext{
${ }^{1}$ TRIGA (Training Research Isotope General Atomic) is a registered trademark of General Atomics.
}
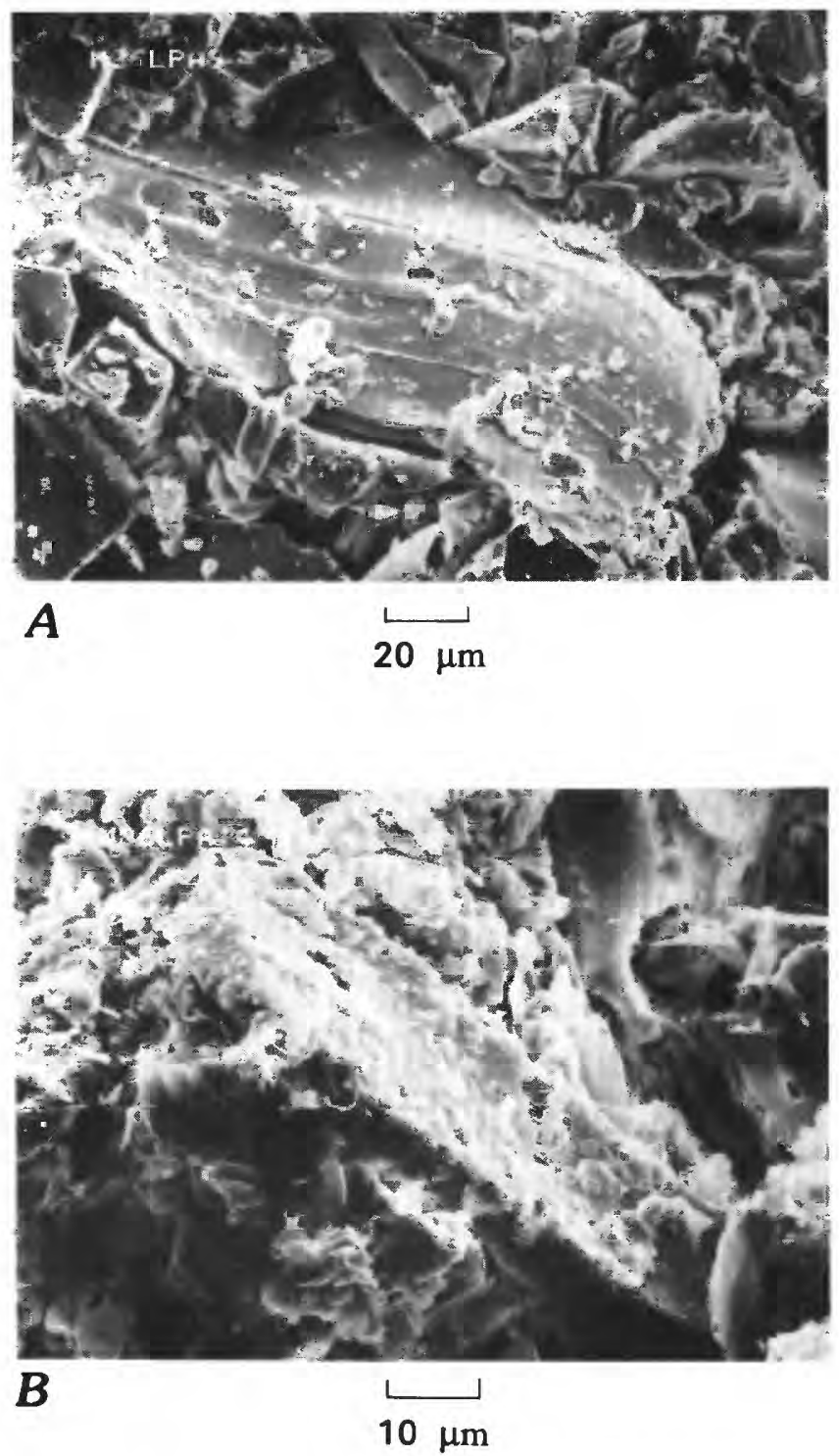

Figure 3. Scanning electron micrographs of untreated glass shards from Colville River tephra beds. A, Sample M86LPA9 shows little surface alteration and produced an undisturbed ${ }^{40} \mathrm{Ar} /{ }^{39} \mathrm{Ar}$ age spectrum. B, Sample M86LPA14 has significantly more surface alteration and showed evidence of recoil in ${ }^{40} \mathrm{Ar} /{ }^{39} \mathrm{Ar}$ analysis. See figure 1 for sample locations. 
Table 1. Results of conventional K-Ar analyses of Colville River tephra beds

[Samples listed in probable stratigraphic order, with sample from lowermost tephra bed at bottom of table. rad, radiogenic; $\sigma$, standard deviation. Constants: $\left.\lambda_{\varepsilon}+\lambda_{\varepsilon}^{\prime}=0.581 \times 10^{-10} \mathrm{yr}^{-1}, \lambda_{\beta}=4.962 \times 10^{-10} \mathrm{yr}^{-1}, 40 \mathrm{~K} / \mathrm{K}_{\text {total }}=1.167 \times 10^{-4} \mathrm{~mol} / \mathrm{mol}\right]$

\begin{tabular}{lcccccc}
\hline $\begin{array}{l}\text { Sample } \\
\text { number }\end{array}$ & $\begin{array}{c}\text { Experiment } \\
\text { number }\end{array}$ & Material & $\begin{array}{c}\mathrm{K}_{2} \mathrm{O} \\
\text { (weight } \\
\text { percent) }\end{array}$ & $\begin{array}{c}{ }^{40} \mathrm{Ar} \mathrm{rad} \\
(\mathrm{mole} / \mathrm{g} \\
\times 10^{-10}\end{array}$ & $\begin{array}{c}40 \mathrm{Ar} \text { rad } \\
\text { (percent) }\end{array}$ & $\begin{array}{c}\text { Age } \pm 1 \sigma \\
(\mathrm{Ma})\end{array}$ \\
\hline M86LPA9 & 871589 & Glass & 5.74 & 5.811 & 88.8 & $69.5 \pm 2.1$ \\
86ACr019 & 871535 & Glass & 3.87 & 3.732 & 77.0 & $65.8 \pm 2.0$ \\
M86LPA14 & 871590 & Glass & 3.83 & 3.817 & 70.7 & $68.5 \pm 2.0$ \\
M86LPA19 & 871452 & Glass & 5.46 & 5.647 & 76.7 & $70.4 \pm 2.1$ \\
\hline
\end{tabular}

flux was monitored by use of the SB-3 biotite standard, which has an age of $162.9 \mathrm{Ma}$. Heating steps were onehalf-hour intervals with higher temperatures (greater than about $750^{\circ} \mathrm{C}$ ) monitored by optical pyrometer. Temperatures of lower temperature steps are approximate, based on extrapolation from higher temperature steps along known curves of RF (radio-frequency) generator power plotted against temperature. Isotopic analyses were made at the U.S. Geological Survey in Menlo Park, Calif., using a multiple-collector mass spectrometer (Stacey and others, 1981). Sample handling techniques and corrections for calcium- and potassium-derived isotopes used in the Menlo Park laboratory are as described by Dalrymple and Lanphere $(1971,1974)$.

Samples used for the laser-heating analyses were irradiated in the TRIGA reactor at the University of California, Berkeley. Irradiation flux was monitored by use of standards MMhb-1 hornblende, with an age of $520.4 \mathrm{Ma}$, GHC 305 biotite, with an age of $103.76 \mathrm{Ma}$, and P-207 muscovite, with an age of $82.1 \mathrm{Ma}$. The following potassium and calcium corrections for the UC Berkeley TRIGA reactor were determined using optical grade $\mathrm{CaF}_{2}$ and a laboratory potassium glass: ${ }^{40} \mathrm{Ar}_{\mathrm{K}} /{ }^{39} \mathrm{Ar}_{\mathrm{K}}=0.0086$; ${ }^{39} \mathrm{Ar}_{\mathrm{Ca}} /{ }^{37} \mathrm{Ar}_{\mathrm{Ca}}=0.0003$; and ${ }^{36} \mathrm{Ar}_{\mathrm{Ca}} /{ }^{37} \mathrm{Ar}_{\mathrm{Ca}}=0.0003$.

The laser-heated ${ }^{40} \mathrm{Ar} /{ }^{39} \mathrm{Ar}$ extractions and isotopic analyses were conducted at the Geochronology Center at the Institute of Human Origins (Berkeley, Calif.) using a laser-fusion microextraction system and an online, ultrasensitive mass spectrometer. Argon backgrounds for this system are approximately the following: ${ }^{40} \mathrm{Ar}=4.0 \times 10^{-12}$ $\mathrm{cm}^{3}$ (STP); ${ }^{39} \mathrm{Ar}=1.0 \times 10^{-13} \mathrm{~cm}^{3}$ (STP); ${ }^{37} \mathrm{Ar}=7.6 \times 10^{-14} \mathrm{~cm}^{3}$ (STP); and ${ }^{36} \mathrm{Ar}=3.9 \times 10^{-14} \mathrm{~cm}^{3}$ (STP). Detection limit for this mass spectrometer is on the order of $1.0 \times 10^{-14} \mathrm{~cm}^{3}$ (STP). Use of laser-light energy for fusion greatly reduces the background argon because there is less nonfocused heating and subsequent outgassing of the ultrahigh vacuum system. This system is designed to analyze samples as small as single grains (less than $0.1 \mathrm{mg}$ ), but its chief advantage for this study is that as many as four individual fusions and analyses per hour are possible. For the age-spectrum experiments, less than about $0.25 \mathrm{mg}$ (approximately 30 to 40 shards) was used. The temperature of the heating steps for the laser-heating experiments was not determined; progressive heating of the sample was achieved by gradually increasing laser output at each heating step to produce roughly equivalent gas fractions as determined by trial and error. Laser output started at 0.5 watts for the initial heating steps and was increased at 0.25 - to 0.5 -watt increments until fusion occurred. The duration of each heating step was approximately 20 seconds.

The decay constants used in the age calculations are those recommended by Steiger and Jäger (1977). Reported errors are an estimate of the standard deviation of analytical precision and were calculated using standard propagation-of-error methods (Taylor, 1982).

\section{RESULTS}

\section{Conventional K-Ar Analyses}

Conventional K-Ar ages on the Colville River tephra beds range from $65.8 \pm 2.0$ to $70.4 \pm 2.1 \mathrm{Ma}$ (table 1). The four samples listed in table 1 (see also fig. 1) are in probable stratigraphic order. (Sample 84ACr180Y is absent from table 1 because it was not dated by the K-Ar method.) Faults and covered intervals in the section prohibit a direct correlation between some of the dated tephra units, but in general correlation is good, and the section becomes younger to the northeast judging from the dip of the beds. Within the limits of analytical uncertainty, the ages are indistinguishable from one another, so these data are consistent with a general northeasterly younging of the section across faults and covered intervals. The age of sample $86 \mathrm{ACr} 019$ is concordant with the other ages, but ${ }^{40} \mathrm{Ar} /{ }^{39} \mathrm{Ar}$ data (described later) suggest that this sample may have undergone some argon loss. The $\mathrm{K}$-Ar data indicate that the age of these beds ranges from about $70-71$ Ma to about 66-68 Ma.

\section{${ }^{40} \mathrm{Ar} /{ }^{39} \mathrm{Ar}$ Analyses}

${ }^{40} \mathrm{Ar} /{ }^{39} \mathrm{Ar}$ analyses were performed to explore the possibility that some or all of the conventional K-Ar ages 
may be too young. Anomalously young ages could result if the glass has lost argon via diffusion or alteration. The ${ }^{40} \mathrm{Ar} /{ }^{39} \mathrm{Ar}$ incremental, or age-spectrum, technique is used to evaluate the possibility of argon loss or redistribution caused by reheating or alteration of minerals. Although it is rarely used on terrestrial volcanic glasses, the fundamental concepts of the ${ }^{40} \mathrm{Ar} /{ }^{39} \mathrm{Ar}$ spectrum technique (Lanphere and Dalrymple, 1978) are the same as when applied to crystalline materials. A sample is heated to progressively higher temperatures, and a series of ages, termed apparent ages, is calculated from the argon expelled at each temperature step. Typically, a history of alteration or reheating of a mineral sample will result in younger ages for the low-temperature steps. Higher temperature steps will produce older ages that may form a plateau around a value thought to reflect the true cooling age of the rock. In general, this pattern is attributed to a higher argon retentiveness of the high-temperature sites in the crystal lattice. Although glass is not directly comparable to minerals in that it lacks a well-developed crystal structure, ${ }^{40} \mathrm{Ar} /{ }^{39} \mathrm{Ar}$ incremental heatings can nonetheless give insight into the argon retentiveness of glass. The assumption used for interpreting incremental heatings of glass is that the low-temperature steps (about $300-500^{\circ} \mathrm{C}$ ) release loosely held argon from the outside edges of the glass shards and from alteration products. Higher temperature steps (about $550^{\circ} \mathrm{C}$ and higher) release argon (by volume diffusion) from inner portions of the shards that have been less affected by alteration and diffusion over geologic time. Alteration and diffusion of argon will be most pronounced along the edges of the shards; low-temperature steps will reveal these effects of argon loss by yielding anomalously young apparent ages.

All samples were analyzed by either induction-heating or laser-heating ${ }^{40} \mathrm{Ar} /{ }^{39} \mathrm{Ar}$ techniques, and one sample (M86LPA9) by both methods (table 2). Three of the samples (M86LPA19, 84ACr180Y, M86LPA9) produced well-defined plateaus in the argon-release sequence (fig. $4 A$ ) and show only minor radiogenic argon loss at low-temperature steps. The amount of argon loss can be estimated by comparison of plateau ages and recombined total-fusion ages. In a total-fusion analysis, a sample is completely fused after irradiation and all of the Ar released is analyzed in a single experiment. To simulate this technique, the data can be combined from the incremental Ar releases to calculate a total-fusion age, known as a recombined total-fusion, or total-gas, age for each sample. The recombined total-fusion ages for all samples are about 1 m.y. younger than the plateau ages (table 3 ), indicating loss of radiogenic argon of less than 2.5 percent. Two of the samples (M86LPA14, 86ACr019) give less welldefined plateaus, and their calculated ages appear anomalous on the basis of the inferred stratigraphic sequence. ${ }^{40} \mathrm{Ar} /{ }^{36} \mathrm{Ar}$ versus ${ }^{39} \mathrm{Ar} /{ }^{36} \mathrm{Ar}$ isochron diagrams and
${ }^{36} \mathrm{Ar} /{ }^{40} \mathrm{Ar}$ versus ${ }^{39} \mathrm{Ar} /{ }^{40} \mathrm{Ar}$ correlation diagrams for these samples also show evidence of disturbance (figs. $4 B, 4 C$ ).

\section{Sample M86LPA19}

This tephra bed is inferred to be the oldest unit dated in this study on the basis of its stratigraphic position. Glass from the tephra was dated twice by the age-spectrum method and once by the total-fusion method using laser heating (table 2). The plateau ages from the two age-spectrum experiments are $70.0 \pm 0.9$ and $71.4 \pm 0.6 \mathrm{Ma}$ (table 3). Although temperatures of individual steps were not determined, the general plateau shape is similar to that of samples for which temperatures are known. Both age spectra for this tephra unit show evidence of minor loss of ${ }^{40} \mathrm{Ar}$ in the low-temperature steps. This loss is expressed by young ages in the first step of experiment L115-2, which involved about 7 percent of the total release of ${ }^{39} \mathrm{Ar}$ from the sample, and in the first two steps of experiment L115-3, which involved about 32 percent of the total ${ }^{39} \mathrm{Ar}$ release (fig. 4A). The difference in release patterns between the two experiments may be due to inhomogeneous heating by the laser heat source, leading to incomplete degassing at the lower temperature steps. In spite of this inconsistency, total radiogenic ${ }^{40} \mathrm{Ar}$ loss, estimated by comparison of the recombined total-fusion ages with the plateau ages, is less than about 2 percent in each analysis.

Ages calculated from the ${ }^{40} \mathrm{Ar} /{ }^{36} \mathrm{Ar}$ versus ${ }^{39} \mathrm{Ar} /{ }^{36} \mathrm{Ar}$ isochron diagrams (fig. $4 B$ ) and ${ }^{36} \mathrm{Ar} /{ }^{40} \mathrm{Ar}$ versus ${ }^{39} \mathrm{Ar} /{ }^{40} \mathrm{Ar}$ correlation diagrams (fig. $4 \mathrm{C}$ ) for these experiments agree with the plateau ages according to the criteria of Lanphere and Dalrymple (1978). The error estimates $( \pm)$ derived from the isochron and correlation diagrams are slightly higher than those calculated from the plateaus because of the extremely low percentage of atmospheric ${ }^{36} \mathrm{Ar}$ contamination in the laser-fusion line. ${ }^{36} \mathrm{Ar}$ for these samples was typically only slightly above background values, so analytic error is relatively high. In addition, measured ${ }^{40} \mathrm{Ar} /{ }^{36} \mathrm{Ar}$ ratios, especially for the higher temperature plateau steps, are greater than about 3,000 (fig. $4 B$ ), so that the isochron must be projected relatively far back to the axis from which the initial ${ }^{40} \mathrm{Ar} /{ }^{36} \mathrm{Ar}$ ratio is derived. The combined effect of these factors is that the ages calculated from the isochron and correlation diagrams have errors approximately 2 to 3 times those indicated by the plateau calculations, but in all cases agree with the plateau ages within the error limits. Initial ${ }^{40} \mathrm{Ar} /{ }^{36} \mathrm{Ar}$ ratios also have large errors-of as much as 100 percent or more-due to the low ${ }^{36} \mathrm{Ar}$ content, but in both experiments, initial ${ }^{40} \mathrm{Ar} /{ }^{36} \mathrm{Ar}$ ratios were consistent with the expected ratio of 295.5, the ratio of ${ }^{40} \mathrm{Ar}$ to ${ }^{36} \mathrm{Ar}$ in air. The goodness-of-fit index for the regression of the lines in the isochron and correlation diagrams, given by SUMS/(N-2), ranges from 0.01 to 0.18 . Values greater than about 2.5 indicate the presence of geologic 
error (Lanphere and Dalrymple, 1978); values less than 1.0 indicate that the scatter of points on the line is less than can be expected due to analytical error. In these experiments, values significantly less than 1.0 for the goodness- of-fit index suggest that the experimental errors were overestimated. The goodness-of-fit index nonetheless provides strong evidence that the tephra gives an undisturbed and geologically meaningful plateau age.

Table 2. Results of ${ }^{40} \mathrm{Ar} /{ }^{39} \mathrm{Ar}$ analyses of Colville River tephra beds

[Samples listed in probable stratigraphic order, with sample from lowermost tephra bed at end of table. Bold italic entries indicate data used in calculation of plateau and isochron ages. In third column, temperatures $\left({ }^{\circ} \mathrm{C}\right)$ are reported for samples heated by induction coil, lettered steps for samples heated by continuous laser; TFU means total fusion. J, parameter used in age calculations; rad, radiogenic. Decay constants: $\lambda_{\mathcal{E}}+\lambda_{\varepsilon}^{\prime}=$ $\left.0.581 \times 10^{-10} \mathrm{yr}^{-1}, \lambda_{\beta}=4.962 \times 10^{-10} \mathrm{yr}^{-1}, 40 \mathrm{~K} / \mathrm{K}_{\text {total }}=1.167 \times 10^{-4} \mathrm{~mol} / \mathrm{mol}\right]$

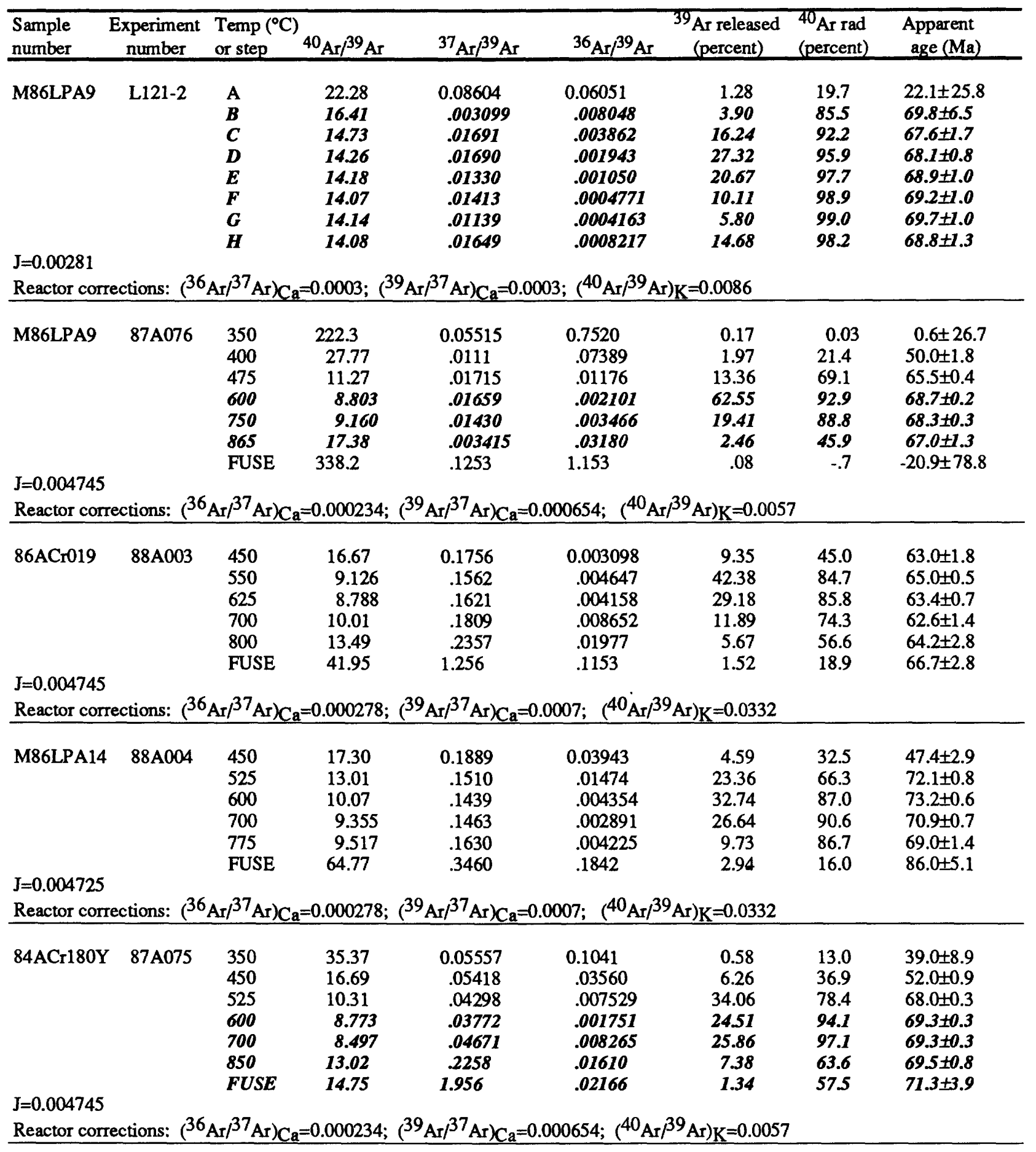


Table 2. Results of ${ }^{40} \mathrm{Ar} /{ }^{39} \mathrm{Ar}$ analyses of Colville River tephra beds-Continued

[Samples listed in probable stratigraphic order, with sample from lowermost tephra bed at end of table. Bold italic entries indicate data used in calculation of plateau and isochron ages. In third column, temperatures $\left({ }^{\circ} \mathrm{C}\right)$ are reported for samples heated by induction coil, lettered steps for samples heated by continuous laser; TFU means total fusion. J, parameter used in age calculations; rad, radiogenic. Decay constants: $\lambda_{\varepsilon}+\lambda_{\varepsilon}^{\prime}=$ $\left.0.581 \times 10^{-10} \mathrm{yr}^{-1}, \lambda_{\beta}=4.962 \times 10^{-10} \mathrm{yr}^{-1}, 40_{\mathrm{K} / \mathrm{K}_{\text {total }}}=1.167 \times 10^{-4} \mathrm{~mol} / \mathrm{mol}\right]$

\begin{tabular}{|c|c|c|c|c|c|c|c|c|}
\hline $\begin{array}{l}\text { Sample } \\
\text { number }\end{array}$ & $\begin{array}{c}\text { Experiment } \\
\text { number }\end{array}$ & $\begin{array}{l}\text { Temp }\left({ }^{\circ} \mathrm{C}\right) \\
\text { or step }\end{array}$ & ${ }^{40} \mathrm{Ar} /{ }^{39} \mathrm{Ar}$ & ${ }^{37} \mathrm{Ar} /{ }^{39} \mathrm{Ar}$ & ${ }^{36} \mathrm{Ar} /{ }^{39} \mathrm{Ar}$ & $\begin{array}{l}{ }^{39} \text { Ar released } \\
\text { (percent) }\end{array}$ & $\begin{array}{c}\text { Radiogenic } \\
{ }^{40} \mathrm{Ar}\end{array}$ & $\begin{array}{c}\text { Apparent } \\
\text { age (Ma) }\end{array}$ \\
\hline \multirow[t]{3}{*}{ M86LPA19 } & L115-1 & TFU & 15.29 & 0.02571 & 0.005813 & 100 & 88.7 & $67.5 \pm 1.5$ \\
\hline & L115-2 & $\begin{array}{l}\text { A } \\
B \\
C \\
D \\
E \\
F \\
G\end{array}$ & $\begin{array}{l}18.15 \\
15.36 \\
14.88 \\
14.85 \\
14.87 \\
14.45 \\
14.77\end{array}$ & $\begin{array}{r}0.07131 \\
.03294 \\
.02771 \\
.02393 \\
.03198 \\
.03979 \\
.02632\end{array}$ & $\begin{array}{l}.02405 \\
.004176 \\
.002610 \\
.003381 \\
.003107 \\
.001380 \\
.001768\end{array}$ & $\begin{array}{r}6.29 \\
20.85 \\
17.40 \\
20.15 \\
11.37 \\
1.83 \\
22.12\end{array}$ & $\begin{array}{l}60.8 \\
91.9 \\
94.8 \\
93.2 \\
93.8 \\
97.1 \\
96.4\end{array}$ & $\begin{array}{l}55.1 \pm 7.4 \\
70.2 \pm 2.4 \\
70.1 \pm 2.1 \\
68.8 \pm 2.0 \\
69.3 \pm 2.9 \\
69.8 \pm 3.0 \\
70.8 \pm 1.4\end{array}$ \\
\hline & L115-3 & $\begin{array}{l}\text { A } \\
\text { B } \\
C \\
D \\
E \\
F\end{array}$ & $\begin{array}{l}17.34 \\
15.01 \\
14.77 \\
14.65 \\
14.92 \\
15.03\end{array}$ & $\begin{array}{c}0.007356 \\
.02244 \\
.02248 \\
.01742 \\
.01306 \\
.01364\end{array}$ & $\begin{array}{l}0.01290 \\
.003973 \\
.001475 \\
.0007919 \\
.001839 \\
.002773\end{array}$ & $\begin{array}{r}2.80 \\
28.68 \\
47.44 \\
15.67 \\
2.76 \\
2.64\end{array}$ & $\begin{array}{l}78.0 \\
92.1 \\
97.0 \\
98.4 \\
96.3 \\
94.5\end{array}$ & $\begin{array}{l}67.3 \pm 4.2 \\
68.8 \pm 0.6 \\
71.2 \pm 0.8 \\
71.6 \pm 0.7 \\
71.4 \pm 3.3 \\
70.6 \pm 3.4\end{array}$ \\
\hline $\begin{array}{l}\mathrm{J}=0.00281 \\
\text { Reactor corr }\end{array}$ & rections: ${ }^{3}$ & $\left.\beta^{37} \mathrm{Ar}\right) \mathrm{C}$ & 0003 & Ar) $\mathrm{Ca}_{\mathrm{a}}=$ & $\left({ }^{40} \mathrm{Ar}\right)^{35}$ & $z=0.0086$ & & \\
\hline
\end{tabular}

\section{Sample 84ACr180Y}

Sample $84 \mathrm{ACr} 180 \mathrm{Y}$ was collected from a tephra bed inferred to be the second oldest in the area of study. A fault of unknown displacement separates it from the M86LPA 19 tephra bed, the oldest tephra in the study area. Conventional induction-heated ${ }^{40} \mathrm{Ar} /{ }^{\beta 9} \mathrm{Ar}$ incremental-heating analysis on glass from this tephra sample gives a plateau age of $69.3 \pm 0.4 \mathrm{Ma}$ (table 3). Minor radiogenic ${ }^{40} \mathrm{Ar}$ loss is apparent in the $350-, 450-$, and $525-{ }^{\circ} \mathrm{C}$ steps (fig. $4 A$, table 2), which total nearly 41 percent of the total ${ }^{39} \mathrm{Ar}$ release. Comparison with the recombined total-fusion age of $67.6 \pm 0.4 \mathrm{Ma}$ (table 3) indicates that total radiogenic ${ }^{40} \mathrm{Ar}$ loss is about 2.5 percent. The ${ }^{40} \mathrm{Ar} /{ }^{36} \mathrm{Ar}$ versus ${ }^{39} \mathrm{Ar} /{ }^{36} \mathrm{Ar}$ isochron diagram (fig. $4 B$ ) and ${ }^{36} \mathrm{Ar} /{ }^{40} \mathrm{Ar}$ versus ${ }^{39} \mathrm{Ar} /{ }^{40} \mathrm{Ar}$ correlation diagram (fig. $4 \mathrm{C}$ ) yield identical ages of $69.3 \pm 0.4 \mathrm{Ma}$ and initial ${ }^{40} \mathrm{Ar} /{ }^{36} \mathrm{Ar}$ ratios of $297.9 \pm 6.1$ and 298.0 6 .1, respectively; these ratios are identical to the expected value of 295.5 . The values of SUMS/(N-2) are about 0.08 and 0.09 for these diagrams, suggesting that the age is geologically accurate. Inclusion of the $525-{ }^{\circ} \mathrm{C}$ step on the plateau does not significantly change the plateau age or the ages derived from the isotope and correlation diagrams, but it changes the SUMS/(N-2) value for the diagrams to about 5, suggesting geologic error, in this case most likely due to minor radiogenic ${ }^{40} \mathrm{Ar}$ loss.

\section{Sample M86LPA14}

Sample M86LPA14 was taken from a tephra bed about $18 \mathrm{~m}$ stratigraphically above the $84 \mathrm{ACr} 180 \mathrm{Y}$ tephra bed. ${ }^{40} \mathrm{Ar} /{ }^{39} \mathrm{Ar}$ age-spectrum analysis suggests some disturbance of argon in this sample. As in the two previous samples, the initial low-temperature $\left(450{ }^{\circ} \mathrm{C}\right)$ step shows evidence of radiogenic ${ }^{40} \mathrm{Ar}$ loss; it is followed by an apparent plateau defined by the 525-, 600-, 700-, and $775-{ }^{\circ} \mathrm{C}$ steps (fig $4 A$ ). This plateau, however, shows significantly more scatter than those of the previous samples, with apparent ages ranging from 69.0 to $73.2 \mathrm{Ma}$ (table 2). The ${ }^{40} \mathrm{Ar} /{ }^{36} \mathrm{Ar}$ versus ${ }^{39} \mathrm{Ar} /{ }^{36} \mathrm{Ar}$ isochron diagram (fig. $4 B$ ) and the ${ }^{36} \mathrm{Ar} /{ }^{40} \mathrm{Ar}$ versus ${ }^{39} \mathrm{Ar} /{ }^{40} \mathrm{Ar}$ correlation diagram (fig. $4 C$ ) also suggest that there is some argon redistribution in this sample. No combination of steps from the apparent plateau yields ages in the isochron and correlation diagrams that are concordant with the corresponding plateau age and have a SUMS/(N-2) value of less than about 4; most combinations give higher values. Initial ${ }^{40} \mathrm{Ar} /{ }^{36} \mathrm{Ar}$ values are highly variable and range from about 120 to more than 500 (expected value is 295.5), depending on the heating increments used in the regression. One explanation for the anomalous data for this sample is that it contains extremely fine-grained alteration products, most likely clays, that have lost small amounts of ${ }^{39} \mathrm{Ar}$ by recoil during or shortly after irradiation, thus giving slightly old apparent ages. Samples of glass shards from this tephra unit viewed under the scanning electron microscope (fig. 3) show significantly more surface alteration than shards that give apparently undisturbed spectra. This alteration may have penetrated the glass from this tephra bed deeply enough that the hydrofluoric acid treatment did not remove 

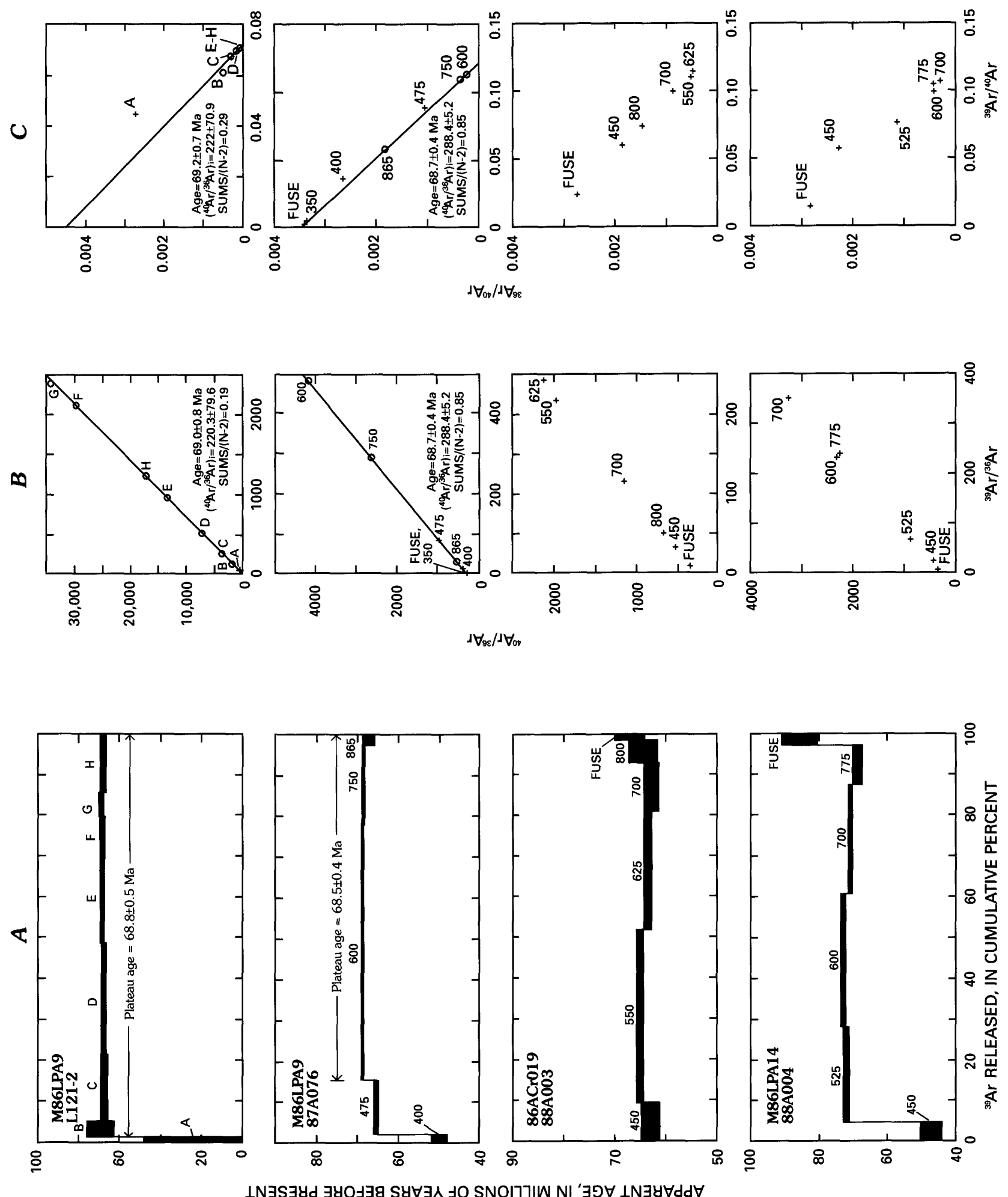





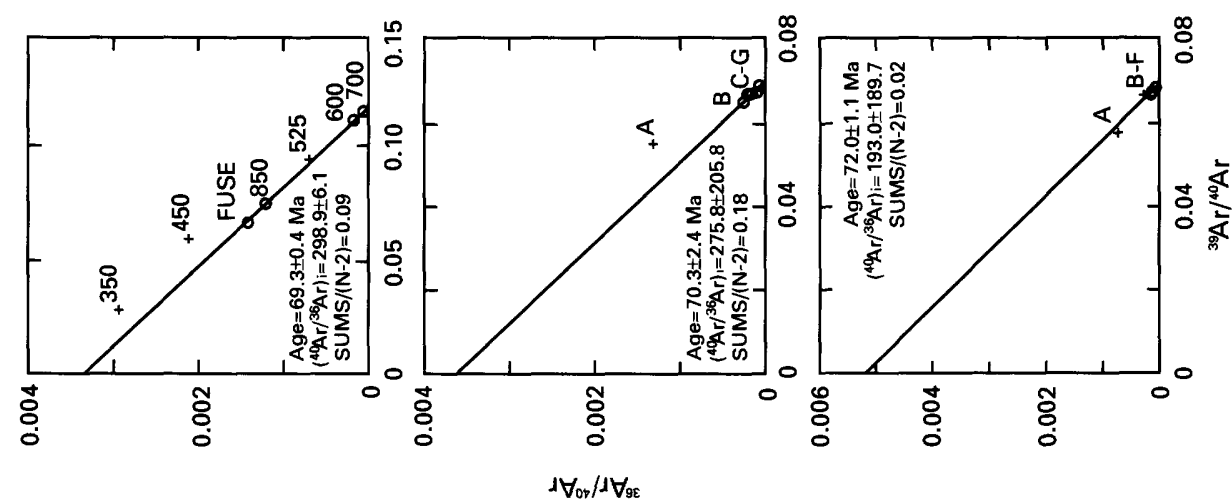

$1 \forall_{0 r} / 1 \forall$
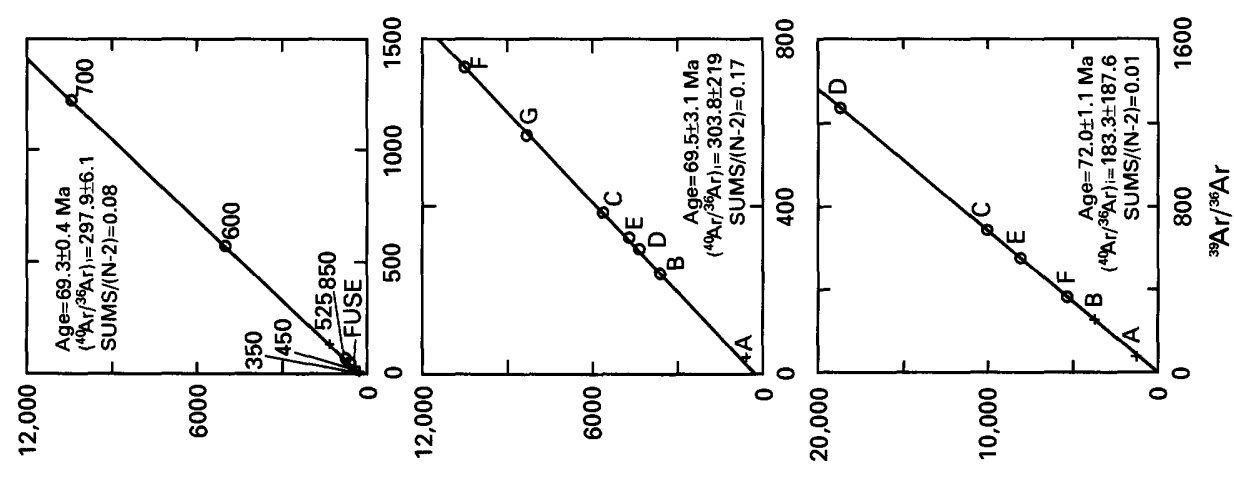

$\perp \forall_{9 \varepsilon} / \Delta \forall_{0 r}$
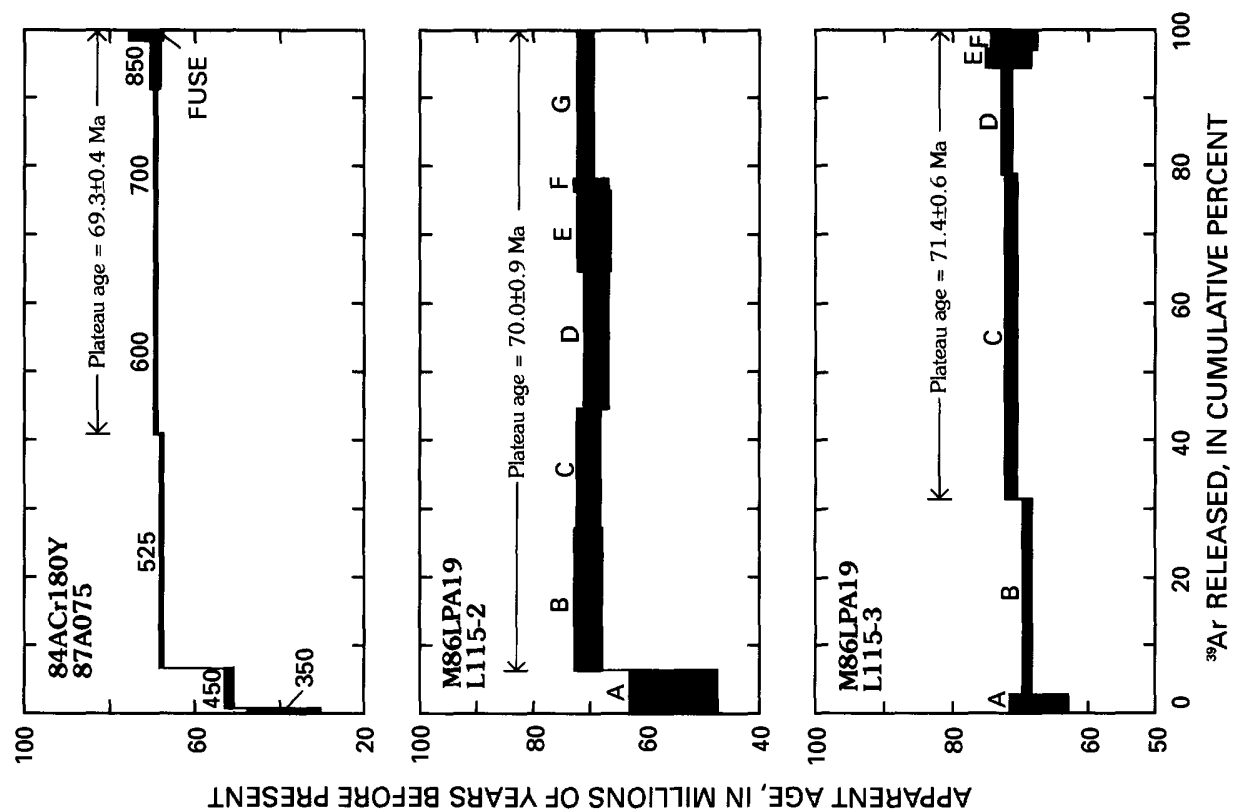

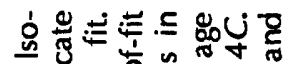

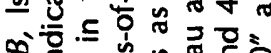

$\infty . \leq$ 象



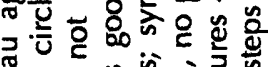

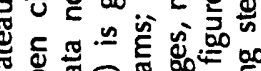

等

过 릉



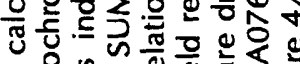

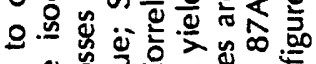

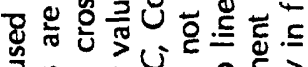



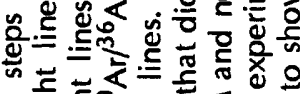

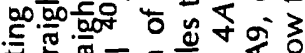

要的要



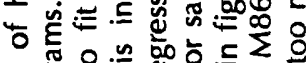

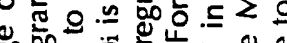

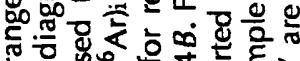



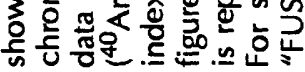

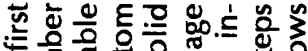

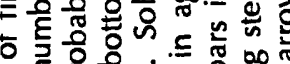

空

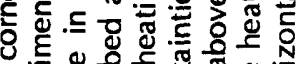





윽뭉 탐

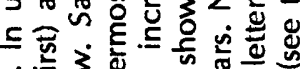

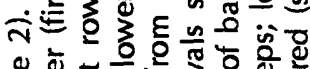

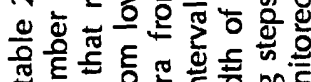

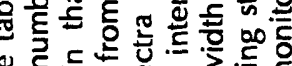
迸

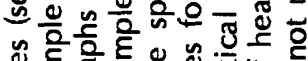

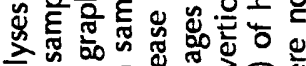

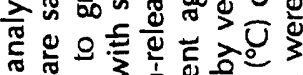

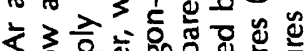

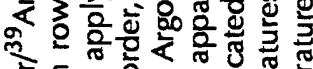

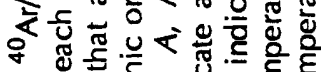
$\checkmark . \leq$ 웜



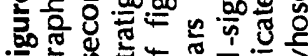


Table 3. Summary of $\mathrm{K}-\mathrm{Ar}$ and ${ }^{40} \mathrm{Ar} /{ }^{39} \mathrm{Ar}$ ages of Colville River tephra beds

[Samples listed in probable stratigraphic order, with sample from lowemost tephra bed at bottom of table. -.-, not determined]

\begin{tabular}{|c|c|c|c|c|c|}
\hline $\begin{array}{l}\text { Sample } \\
\text { number }\end{array}$ & $\begin{array}{l}\text { Experiment } \\
\text { number }\end{array}$ & $\begin{array}{c}\mathrm{K}-\mathrm{Ar} \\
\text { age (Ma) }\end{array}$ & $\begin{array}{c}{ }^{40} \mathrm{Ar} /{ }^{39} \mathrm{Ar} \\
\text { plateau age }(\mathrm{Ma})\end{array}$ & $\begin{array}{c}{ }^{40} \mathrm{Ar} /{ }^{39} \mathrm{Ar} \\
\text { isochron age }(\mathrm{Ma})\end{array}$ & $\begin{array}{l}{ }^{40} \mathrm{Ar} /{ }^{39} \mathrm{Ar} \text { total- } \\
\text { fusion age (Ma) }\end{array}$ \\
\hline M86LPA9----- & $\begin{array}{l}\text { L121-2 } \\
\text { 87A076 } \\
871589\end{array}$ & $\begin{array}{c}-- \\
-- \\
69.5 \pm 2.1\end{array}$ & $\begin{array}{l}68.8 \pm 0.5 \\
68.5 \pm 0.4\end{array}$ & $\begin{array}{c}69.0 \pm 0.8 \\
68.7 \pm 0.4 \\
---\end{array}$ & $\begin{array}{l}68.0 \pm 0.7^{*} \\
67.6 \pm 0.4^{*} \\
\end{array}$ \\
\hline 86ACr019--.-- & $\begin{array}{l}88 \mathrm{~A} 003 \\
871535\end{array}$ & $65.8 \pm 2.0$ & No plateau & --- & 64.1 $1 \pm 0.5^{*}$ \\
\hline M86LPA14--- & $\begin{array}{l}88 \mathrm{~A} 004 \\
871590\end{array}$ & $68 . \overline{--}$ & No plateau & -- & 71.1 $10.5^{*}$ \\
\hline 84ACr180Y--- & $87 \mathrm{~A} 075$ & -- & $69.3 \pm 0.4$ & $69.3 \pm 0.4$ & $67.6 \pm 0.4^{*}$ \\
\hline M86LPA19---- & $\begin{array}{l}\text { L115-1 } \\
\text { L115-2 } \\
\text { L115-3 } \\
871452\end{array}$ & $\begin{array}{c}--- \\
-- \\
--- \\
70.4 \pm 2.1\end{array}$ & $\begin{array}{c}70.0 \pm 0.9 \\
71.4 \pm 0.6 \\
---\end{array}$ & $\begin{array}{c}-- \\
69.5 \pm 3.1 \\
72.0 \pm 1.1 \\
\ldots\end{array}$ & $\begin{array}{c}67.5 \pm 1.5 \\
69.0 \pm 1.0^{*} \\
70.4 \pm 0.6^{*} \\
\ldots--\end{array}$ \\
\hline
\end{tabular}

${ }^{*}$ Recombined age.

all the alteration products. The conventional K-Ar analysis of this sample gave an age of $68.5 \pm 2.0 \mathrm{Ma}$, analytically indistinguishable from the age of the underlying tephra bed (see table 2). Thus, alteration of this tephra bed, which appears to have caused some argon redistribution, apparently did not result in appreciable loss of radiogenic ${ }^{40} \mathrm{Ar}$.

\section{Sample 86ACr019}

Sample 86ACr019 was taken from a tephra bed several meters stratigraphically above two major dinosaur-bonebearing beds and about $3 \mathrm{~m}$ below a third bone bed. This tephra bed is inferred to be the second youngest in this study, although a covered interval separates this part of the section from the three tephra beds described in the previous paragraphs, and a fault of unknown displacement separates it from the younger beds to the east (figs. 1, 2). ${ }^{40} \mathrm{Ar} /{ }^{39} \mathrm{Ar}$ age-spectrum analysis of this sample reflects some degree of argon loss and (or) redistribution. Although a plateau appears to be present at about $64 \mathrm{Ma}$ (table 2), the overall shape of the plateau is similar to that of sample M86LPA14, which is interpreted to indicate a disturbed age (fig. $4 A$ ). The initial $450-{ }^{\circ} \mathrm{C}$ step gives a slightly young age, and it is followed by a series of steadily decreasing ages for the middle-temperature steps. The final two steps give slightly higher ages, similar to the final step for M86LPA14. Moreover, the apparent plateau age of about $64 \mathrm{Ma}$ is slightly young on the basis of the ages of the other samples. The ${ }^{40} \mathrm{Ar} /{ }^{36} \mathrm{Ar}$ versus ${ }^{39} \mathrm{Ar} /{ }^{36} \mathrm{Ar}$ isochron diagram (fig. $4 B$ ) and ${ }^{36} \mathrm{Ar} /{ }^{40} \mathrm{Ar}$ versus ${ }^{39} \mathrm{Ar} /{ }^{40} \mathrm{Ar}$ correlation diagram (fig. $4 C$ ) bear out the conclusion that this sample is slightly disturbed. Ages calculated from the isochron and correlation diagrams are concordant with the age calculated from the apparent plateau, and initial ${ }^{40} \mathrm{Ar} /{ }^{36} \mathrm{Ar}$ ratios are close to 295.5 , but the goodness-of-fit index, SUMS $/(\mathrm{N}-2)$, is about 3.5, indicative of geologic error. The pattern of steadily decreasing ages of the plateau steps is a characteristic of recoil of ${ }^{39} \mathrm{Ar}$ after irradiation. The young apparent ages, however, are not typical of recoil but instead suggest loss of radiogenic ${ }^{40} \mathrm{Ar}$. Possibly, devitrification and recrystallization of very fine grained alteration products that were susceptible to ${ }^{39} \mathrm{Ar}$ recoil in the reactor also led to significant loss of radiogenic ${ }^{40} \mathrm{Ar}$ over geologic time. This age spectrum is in contrast to that of M86LPA14, which apparently was affected by recoil effects but does not show evidence of argon loss.

\section{Sample M86LPA9}

Sample M86LPA9 is from the youngest tephra bed exposed near Ocean Point. ${ }^{40} \mathrm{Ar} /{ }^{39} \mathrm{Ar}$ age-spectrum analysis was performed by both induction-heating techniques (experiment 87A076) and laser-heating techniques (experiment L121-2), giving plateau ages of $68.5 \pm 0.4$ and $68.8 \pm 0.5 \mathrm{Ma}$, respectively (table 3 ). Both spectra show very well defined plateaus and similar release patterns (fig. 4A). Only minor loss of radiogenic argon is apparent in the low-temperature release steps. Comparison of the plateau ages with recombined total-fusion ages (table 3) indicates total radiogenic argon loss is less than 1.5 percent for both types of analysis. The ${ }^{40} \mathrm{Ar} /{ }^{36} \mathrm{Ar}$ versus ${ }^{39} \mathrm{Ar} /{ }^{36} \mathrm{Ar}$ isochron diagrams and ${ }^{36} \mathrm{Ar} /{ }^{40} \mathrm{Ar}$ versus ${ }^{39} \mathrm{Ar} /{ }^{40} \mathrm{Ar}$ correlation diagrams for both these analyses also indicate that the plateau ages represent undisturbed ages (figs. $4 B, 4 C$ ). Ages derived from the isochron and correlation diagrams are concordant with the plateau ages, initial ${ }^{40} \mathrm{Ar} /{ }^{36} \mathrm{Ar}$ ratios are not significantly different from 295.5 at a 95-percent confidence level, and the goodness-of-fit indexes (SUMS/(N-2)) are less than 1. 


\section{DISCUSSION}

The results indicate that rhyolitic glass at least as old as Late Cretaceous can give geologically reasonable $\mathrm{K}-\mathrm{Ar}$ and ${ }^{40} \mathrm{Ar} /{ }^{39} \mathrm{Ar}$ radiometric ages. Analysis of age spectra and isochron and correlation diagrams using the criteria of Lanphere and Dalrymple (1978) readily distinguishes between samples that have undergone some degree of argon redistribution and those that are essentially undisturbed and therefore give reliable cooling ages. The ${ }^{40} \mathrm{Ar} /{ }^{39} \mathrm{Ar}$ age spectra for three of the glass samples (M86LPA19, 84ACr180Y, M86LPA9) have concordant, well-defined plateaus and show only minor evidence of argon loss caused by alteration or diffusion. Samples M86LPA14 and $86 \mathrm{ACr} 019$ gave disturbed age spectra and appear to have some degree of argon redistribution, but only one of these (86ACr019) shows evidence of significant argon loss. ${ }^{40} \mathrm{Ar} /{ }^{39} \mathrm{Ar}$ ages derived from isochron diagrams-termed isochron ages-are in general preferred ages because the method by which they are determined minimizes the effects of alteration, and thus argon loss, and takes best account of analytical errors. The plateau and isochron ages also have greater precision than conventional K-Ar ages, in part because they are an average of several individual age determinations.

Although all of the samples show evidence of minor argon loss, three of the five glass samples we dated yielded ages that represent true cooling ages on the basis of normal criteria for analysis of ${ }^{40} \mathrm{Ar} /{ }^{39} \mathrm{Ar}$ age spectra. The minor ( $<2.5$ percent) ${ }^{40} \mathrm{Ar}$ loss observed in the low-temperature heating steps can be attributed to loss of ${ }^{40} \mathrm{Ar}$ due to surface alteration and (or) diffusion near shard boundaries. Nonetheless, the ${ }^{40} \mathrm{Ar} /{ }^{39} \mathrm{Ar}$ ages are indistinguishable from the conventional $\mathrm{K}$-Ar ages within the limits of analytical uncertainty. Of the two samples giving apparently disturbed ${ }^{40} \mathrm{Ar} /{ }^{39} \mathrm{Ar}$ age spectra, one (M86LPA14) gave a $\mathrm{K}$-Ar age $(68.5 \pm 2.0 \mathrm{Ma})$ that is reasonable on the basis of the other radiometric dates, suggesting that some argon redistribution occurred without significant argon loss. The slightly old recombined totalfusion age of $71.1 \pm 0.5 \mathrm{Ma}$ obtained on this sample by ${ }^{40} \mathrm{Ar} /{ }^{39} \mathrm{Ar}$ analysis may be an artifact of the irradiation process (recoil of ${ }^{39} \mathrm{Ar}$ ). Sample 86ACr019 appears to have suffered significant ${ }^{40} \mathrm{Ar}$ loss due to alteration or diffusion on the basis of the incremental heating data. The $\mathrm{K}$-Ar age of $65.8 \pm 2.0 \mathrm{Ma}$ for this sample is therefore considered a minimum age.

The "best" or preferred age for each of the tephra beds is shown in figure 5. For samples M86LPA9 and M86LPA 19, preferred ages are 68.8 \pm 0.4 and $70.4 \pm 0.8 \mathrm{Ma}$, respectively, and are calculated from weighted means of ${ }^{40} \mathrm{Ar} /{ }^{39} \mathrm{Ar}$ isochron ages, ${ }^{40} \mathrm{Ar} /{ }^{39} \mathrm{Ar}$ total-fusion ages, and $\mathrm{K}$-Ar ages for each tephra bed. The preferred age for sample $84 \mathrm{ACr} 180 \mathrm{Y}$ is the ${ }^{40} \mathrm{Ar} /{ }^{39} \mathrm{Ar}$ isochron age of $69.3 \pm 0.4 \mathrm{Ma}$.

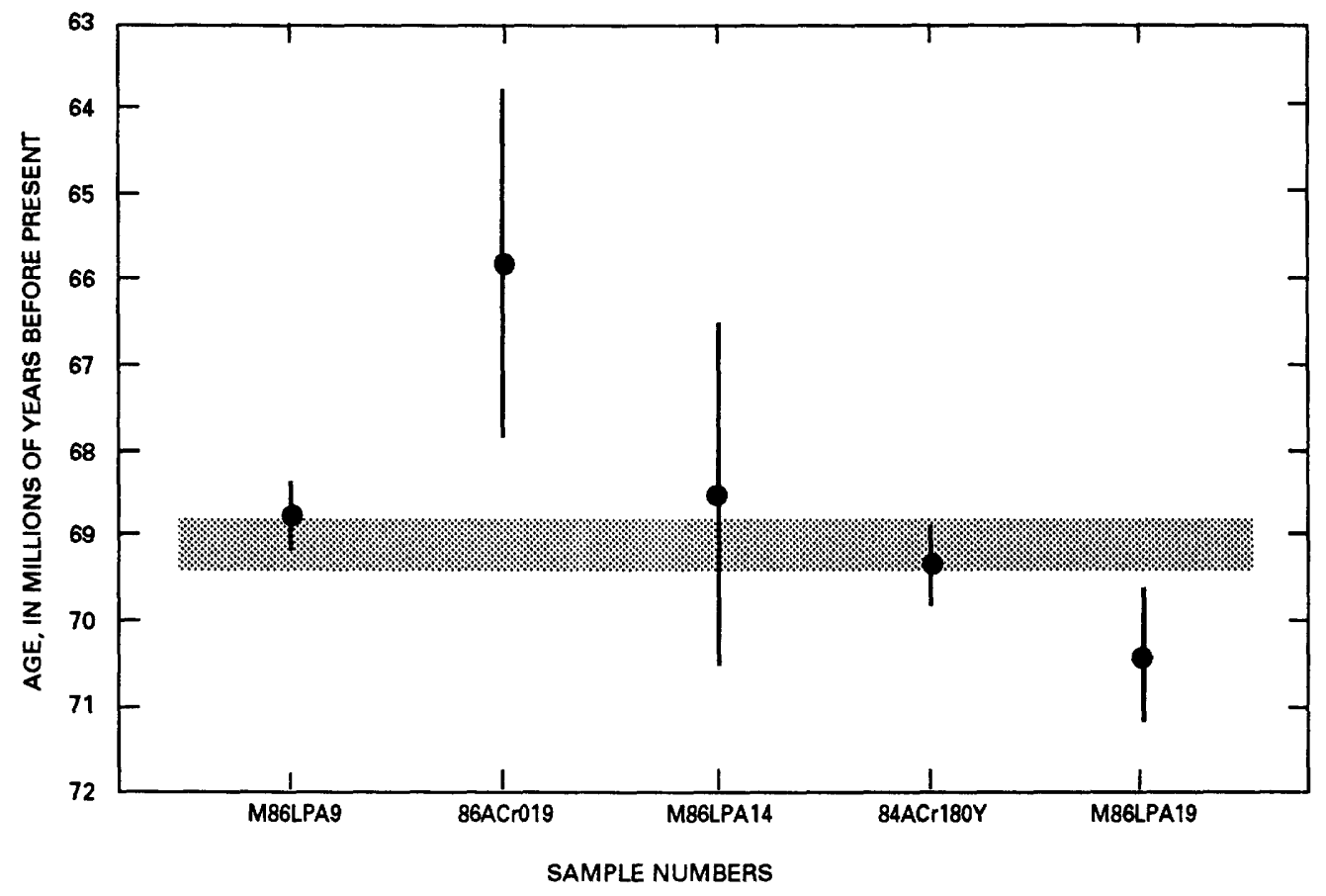

Figure 5. Best age estimates for Colville River tephra beds (dots) and associated 1-sigma errors (bars). Shaded area shows best estimate of age of bone-bearing beds on basis of all analyses. See text for discussion. 
The best age estimate for sample M86LPA14 is the $\mathrm{K}-\mathrm{Ar}$ age of $68.5 \pm 2.0 \mathrm{Ma}$, because of possible irradiationinduced disturbance in the ${ }^{40} \mathrm{Ar} /{ }^{39} \mathrm{Ar}$ analysis. The $\mathrm{K}-\mathrm{Ar}$ age of $65.8 \pm 2.0 \mathrm{Ma}$ for sample $86 \mathrm{ACr} 019$ is considered a minimum age because of significant argon redistribution and loss apparent in the ${ }^{40} \mathrm{Ar} /{ }^{39} \mathrm{Ar}$ analysis. Although there appears to be a slight decrease in age upward through the section, none of the tephra beds are demonstrably different in age at a 95-percent confidence level. Since the ages are concordant, a best age estimate of $69.1 \pm 0.3 \mathrm{Ma}$ for the dinosaur-bonebearing beds was calculated using the weighted mean of all the analyses. Assuming that offsets across the faults and covered intervals are small, the location of the Cretaceous-Tertiary boundary, considered to be about $66 \mathrm{Ma}$ (Palmer, 1983), appears to be at least $100 \mathrm{~m}$ above the youngest dated tephra bed (M86LPA9), provided depositional and environmental conditions remained constant. This new dating, by establishing a Late Cretaceous age for the dinosaur-bone-bearing beds, is compatible with the impact theory for the extinction of the dinosaurs. Unfortunately, no tephra beds have been identified near the probable location of the Cretaceous-Tertiary boundary to allow for $\mathrm{K}-\mathrm{Ar}$ or ${ }^{40} \mathrm{Ar} /{ }^{39} \mathrm{Ar}$ dating. About $40-60 \mathrm{~m}$ above the youngest tephra bed, the section passes into a marine depositional environment (Phillips, 1988). Thus, any tephra beds deposited at this time would likely be reworked and altered by diagenetic interaction with sea water.

\section{REFERENCES CITED}

Alvarez, L.W., Alvarez, Walter, Asaro, Frank, and Michel, H.V., 1980, Extraterrestrial cause for the Cretaceous-Tertiary extinction: Science, v. 208, p. 1095-1108.

Brouwers, E.M., Clemens, W.A., Spicer, R.A., Ager, T.A., Carter, L.D., and Sliter, W.V., 1987, Dinosaurs on the North Slope, Alaska-High latitude, latest Cretaceous environments: Science, v. 237, p. 1608-1610.

Carter, L.D., Repenning, C.A., Marincovich, L.N., Hazel, J.E., Hopkins, D.M., McDougall, Kristen, and Naeser, C.W., 1977, Gubik and pre-Gubik Cenozoic deposits along the Colville River near Ocean Point, North Slope, Alaska: U.S. Geological Survey Circular 751-B, p. B12-B14.

Dalrymple, G.B., and Lanphere, M.A., 1969, Potassium-argon dating: San Francisco, W.H. Freeman Company, 258 p.

$-1971,{ }^{40} \mathrm{Ar} /{ }^{39} \mathrm{Ar}$ technique of K-Ar dating-A comparison with the conventional technique: Earth and Planetary Science Letters, v. 12, p. 300-308.
$1974,{ }^{40} \mathrm{Ar} /{ }^{39} \mathrm{Ar}$ age spectra of some undisturbed terrestrial samples: Geochimica et Cosmochimica Acta, v. 38, p. 715-738.

Detterman, R.L., Reiser, H.N., Brosgé, W.P., and Dutro, J.T., Jr., 1975, Post-Carboniferous stratigraphy, northeastern Alaska: U.S. Geological Survey Professional Paper 886, 46 p.

Fleck, R.J., Sutter, J.F., Elliot, D.H., 1977, Interpretation of discordant ${ }^{40} \mathrm{Ar} /{ }^{39} \mathrm{Ar}$ age-spectra of Mesozoic tholeiites from Antarctica: Geochimica et Cosmochimica Acta, v. 41, p. 15-32.

Gryc, George, Patton, W.W., Jr., and Payne, T.G., 1951, Present Cretaceous stratigraphic nomenclature of northern Alaska: Washington Academy of Sciences Journal, v. 41, no. 5, p. 159-167.

Ingamells, C.O., 1970, Lithium metaborate flux in silicate analysis: Analytica Chimica Acta, v. 52, p. 323-334.

Lanphere, M.A., and Dalrymple, G.B., 1978, The use of ${ }^{40} \mathrm{Ar} /{ }^{39} \mathrm{Ar}$ data in evaluation of disturbed $\mathrm{K}-\mathrm{Ar}$ systems, in Zartman, R.E., ed., Short papers of the Fourth International Conference, geochronology, cosmochronology, isotope geology: U.S. Geological Survey Open-File Report 78-701, p. 241-243.

Marincovich, Louie, Jr., Brouwers, E.M., and Carter, L.D., 1985, Early Tertiary marine fossils from northem Alaska-Implications for Arctic Ocean paleogeography and faunal evolution: Geology, v. 13, p. 770-773.

McDougall, Kristen, 1987, Maestrichtian benthic foraminifers from Ocean Point, North Slope, Alaska: Joumal of Foraminiferal Research, v. 17, no. 4, p. 344-366.

Palmer, A.R., 1983, The Decade of North American Geology 1983 geologic time scale: Geology, v. 11, p. 503-504.

Phillips, R.L., 1988, Measured sections, paleoenvironments, and sample locations near Ocean Point, Alaska: U.S. Geological Survey Open-File Report 88-40.

Stacey, J.S., Sherrill, N.D., Dalrymple, G.B., Lanphere, M.A., and Carpenter, N.V., 1981, A five-collector system for the simultaneous measurement of argon isotopic ratios in a static mass spectrometer: International Journal of Mass Spectrometry Ion Physics, v. 39, p. 167-180.

Steiger, R.H., and Jäger, E., 1977, Subcommission on geochronology-Convention on the use of decay constants in geo- and cosmochronology: Earth and Planetary Science Letters, v. 36, p. 359-362.

Taylor, J.R., 1982, An introduction to error analysis, the study of uncertainties in physical measurements: Oxford University Press, $270 \mathrm{p}$.

York, Derek, Hall, C.M., Yanase, Yotaro, Hanes, J.A., and Kenyon, W.J., $1981,{ }^{40} \mathrm{Ar} /{ }^{39} \mathrm{Ar}$ dating of terrestrial minerals with a continuous laser: Geophysical Research Letters, v. 8, p. 1136-1138. 


\section{SELECTED SERIES OF U.S. GEOLOGICAL SURVEY PUBLICATIONS}

\section{Periodicals}

Earthquakes \& Volcanoes (issued bimonthly).

Preliminary Determination of Epicenters (issued monthly).

\section{Technical Books and Reports}

Professional Papers are mainly comprehensive scientific reports of wide and lasting interest and importance to professional scientists and engineers. Included are reports on the results of resource studies and of topographic, hydrologic, and geologic investigations. They also include collections of related papers addressing different aspects of a single scientific topic.

Bulletins contain significant data and interpretations that are of lasting scientific interest but are generally more limited in scope or geographic coverage than Professional Papers. They include the results of resource studies and of geologic and topographic investigations; as well as collections of short papers related to a specific topic.

Water-Supply Papers are comprehensive reports that present significant interpretive results of hydrologic investigations of wide interest to professional geologists, hydrologists, and engineers. The series covers investigations in all phases of hydrology, including hydrogeology, availability of water, quality of water, and use of water.

Circulars present administrative information or important scientific information of wide popular interest in a format designed for distribution at no cost to the public. Information is usually of short-term interest.

Water-Resources Investigations Reports are papers of an interpretive nature made available to the public outside the formal USGS publications series. Copies are reproduced on request unlike formal USGS publications, and they are also available for public inspection at depositories indicated in USGS catalogs.

Open-File Reports include unpublished manuscript reports, maps, and other material that are made available for public consultation at depositories. They are a nonpermanent form of publication that may be cited in other publications as sources of information.

\section{Maps}

Geologic Quadrangle Maps are multicolor geologic maps on topographic bases in $71 / 2$ - or 15 -minute quadrangle formats (scales mainly $1: 24,000$ or $1: 62,500$ ) showing bedrock, surficial, or engineering geology. Maps generally include brief texts; some maps include structure and columnar sections only.

Geophysical Investigations Maps are on topographic or planimetric bases at various scales; they show results of surveys using geophysical techniques, such as gravity, magnetic, seismic, or radioactivity, which reflect subsurface structures that are of economic or geologic significance. Many maps include correlations with the geology.

Miscellaneous Investigations Series Maps are on planimetric or topographic bases of regular and irregular areas at various scales; they present a wide variety of format and subject matter. The series also includes 7 1/2-minute quadrangle photogeologic maps on planimetric bases which show geology as interpreted from aerial photographs. Series also includes maps of Mars and the Moon.
Coal Investigations Maps are geologic maps on topographic or planimetric bases at various scales showing bedrock or surficial geology, stratigraphy, and structural relations in certain coal-resource areas.

Oll and Gas Investigations Charts show stratigraphic information for certain oil and gas fields and other areas having petroleum potential.

Miscellaneous Field Studies Maps are multicolor or black-andwhite maps on topographic or planimetric bases on quadrangle or irregular areas at various scales. Pre-1971 maps show bedrock geology in relation to specific mining or mineral-deposit problems; post-1971 maps are primarily black-and-white maps on.various subjects such as environmental studies or wilderness mineral investigations.

Hydrologic Investigations Atlases are multicolored or black-andwhite maps on topographic or planimetric bases presenting a wide range of geohydrologic data of both regular and irregular areas; principal scale is $1: 24,000$ and regional studies are at 1:250,000 scale or smaller.

\section{Catalogs}

Permanent catalogs, as well as some others, giving comprehensive listings of U.S. Geological Survey publications are available under the conditions indicated below from the U.S. Geological Survey, Books and Open-File Reports Section, Federal Center, Box 25425, Denver, CO 80225. (See latest Price and Availability List.)

"Publications of the Geological Survey, 1879. 1961" may be purchased by mail and over the counter in paperback book form and as a set of microfiche.

"Publications of the Geological Survey, 1962- 1970" may be purchased by mail and over the counter in paperback book form and as a set of microfiche.

"Publications of the U.S. Geological Survey, 1971- 1981" may be purchased by mail and over the counter in paperback book form (two volumes, publications listing and index) and as a set of microfiche.

Supplements for $1982,1983,1984,1985,1986$, and for subsequent years since the last permanent catalog may be purchased by mail and over the counter in paperback book form.

State catalogs, "List of U.S. Geological Survey Geologic and Water-Supply Reports and Maps For (State)," may be purchased by mail and over the counter in paperback booklet form only.

"Price and Avallability List of U.S. Geological Survey Publications," issued annually, is available free of charge in paperback booklet form only.

Selected coples of a monthly catalog "New Publications of the U.S. Geological Survey" available free of charge by mail or may be obtained over the counter in paperback booklet form only. Those wishing a free subscription to the monthly catalog "New Publications of the U.S. Geological Survey" should write to the U.S. Geological Survey, 582 National Center, Reston, VA 22092.

Note.--Prices of Government publications listed in older catalogs, announcements, and publications may be incorrect. Therefore, the prices charged may differ from the prices in catalogs, announcements, and publications. 


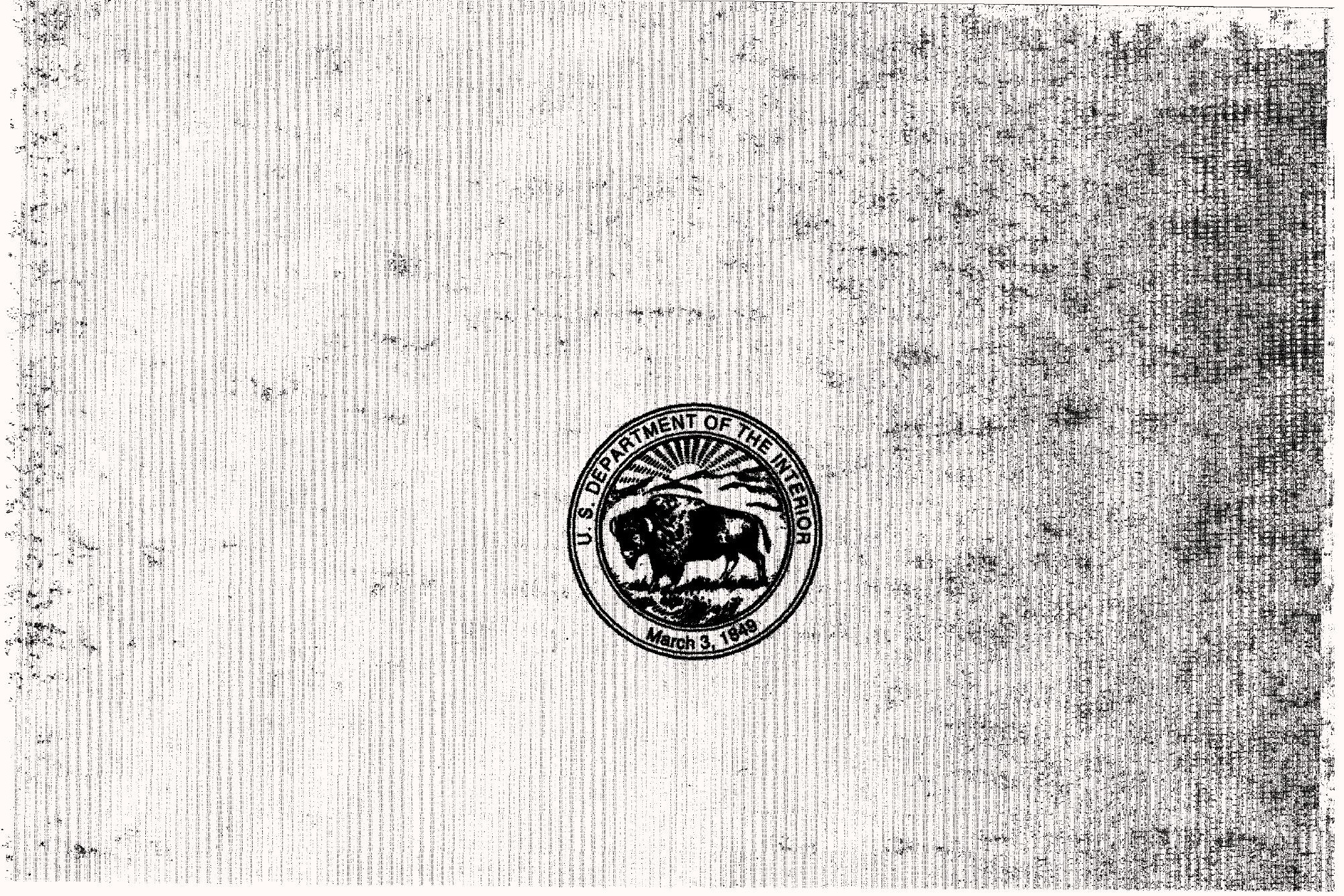

